\title{
Fungsi Pemanfaatan Buku KIA terhadap Pengetahuan Kesehatan Ibu dan Anak pada Ibu
}

\author{
Function of Utilization Maternal Child Health Book to Maternal Knowledge
}

\author{
Colti Sistiarani, Elviera Gamelia, Dyah Umiyarni Purnama Sari
}

Jurusan Kesehatan Masyarakat Fakultas Kedokteran dan Ilmu-ilmu Kesehatan Universitas Jenderal Soedirman

\begin{abstract}
Abstrak
Pemanfaatan buku kesehatan ibu dan anak (KIA) masih belum maksimal terbukti dari data cakupan buku KIA Puskesmas Ajibarang I sekitar 72,34\%, yang masih dibawah target Standar Pelayanan Minimal. Tujuan penelitian ini adalah menganalisis hubungan antara fungsi buku KIA yang meliputi pencatatan, edukasi, dan komunikasi dengan pengetahuan ibu terhadap KIA. Penelitian ini menggunakan desain studi potong lintang, yang dilakukan pada peiode bulan Juni - Oktober 2012, pada ibu di wilayah kerja Puskesmas Ajibarang I. Populasi adalah ibu yang mempunyai anak berusia kurang dari 5 tahun. Sampel diambil sebanyak 91 orang dilakukan dengan teknik proportional random sampling. Analisis data meliputi univariat dengan melakukan uji distribusi frekuensi, dan analisis bivariat dengan uji kai kuadrat $\left(\mathrm{x}^{2}\right)$. Hasil fungsi pencatatan buku KIA kurang baik ditemukan sekitar $44 \%$, fungsi edukasi buku KIA baik sekitar $57,1 \%$, fungsi komunikasi buku KIA baik sekitar $61,5 \%$, dan pengetahuan ibu tentang KIA baik adalah sekitar $56 \%$. Ada hubungan antara fungsi pencatatan buku KIA dengan pengetahuan KIA, tidak ada hubungan antara fungsi edukasi dan komunikasi buku KIA dengan pengetahuan KIA.

Kata kunci: Buku kesehatan ibu dan anak, fungsi pencatatan, pengetahuan ibu
\end{abstract}

\footnotetext{
Abstract

Utilization maternal child health (MCH) book is not maximized, it is evident from the data $\mathrm{MCH}$ book coverage in Ajibarang I Primary Health Care (PHC) was $72.34 \%$, the coverage is still below the target of Minimum Service Standards ( MSS ). The purpose of the study was to analyze relationship between the function of $\mathrm{MCH}$ books (recording, educational, communication) with knowledge of $\mathrm{MCH}$. This study used a cross sectional approach and conducted from June to October 2012, performed to mothers at Ajibarang I PHC. The population were mothers of children aged less than 5 years. Samples were taken of 91 people conducted by proportional random sampling technique. Univariate analysis of the data for the frequency distri-
}

bution test, bivariate chi squared test $\left(\mathrm{x}^{2}\right)$. Results $\mathrm{MCH}$ book recording function less well in the amount of $44 \%$, a good educational functions $\mathrm{MCH}$ book of $57.1 \%$, good communication function $\mathrm{MCH}$ book by $61.5 \%$, and maternal knowledge about the $\mathrm{MCH}$ that is equal to $56 \%$ better. There are relationship between the function of recording $\mathrm{MCH}$ books with knowledge, there is no relationship between education and communication functions with knowledge $\mathrm{MCH}$.

Keywords: Maternal child health books, recording function, maternal knowledge

\section{Pendahuluan}

Indikator derajat kesehatan masyarakat berhubungan erat dengan Angka Kematian Ibu (AKI), Angka Kematian Bayi (AKB). Menurut SDKI 2012, AKI di Indonesia adalah 259 per 100.000 kelahiran hidup. Target AKI secara nasional pada tahun 2015 adalah 102 per 100.000 kelahiran hidup sebagai bentuk komitmen yang dibangun bagian dari Millenium Development Goals/MDGs. ${ }^{1}$

Di Jawa Tengah, pada tahun 2012, Angka Kematian Ibu (AKI) adalah sekitar 116,34 per 100.000 kelahiran hidup. Sekitar 57,93\% kematian maternal terjadi pada waktu nifas, sekitar $24,74 \%$ pada waktu hamil dan seki$\operatorname{tar} 17,33 \%$ pada waktu persalinan. Berdasarkan kelompok umur, kematian maternal terbanyak terjadi pada kelompok usia produktif ( 20 - 34 tahun) sekitar $66,96 \%$, kemudian pada kelompok umur $>35$ tahun sekitar $26,67 \%$ dan pada kelompok umur $<20$ tahun

Alamat Korespondensi: Colti Sistiarani, Jurusan Kesehatan Masyarakat FKIK Unsoed, Kampus Karangwangkal, Jl. Dr. Suparno Purwokerto 53122, Hp. 08122890582,e-mail: coltisistiarani@yahoo.co.id 
sekitar 6,37\%.2 Kasus kematian ibu di Kabupaten Banyumas terdistribusi merata di setiap puskesmas. Pada tahun 2012, jumlah kematian maternal di Kabupaten Banyumas menempati peringkat ke- 6 dari 35 Kabupaten di Jawa Tengah dengan jumlah kematian sebanyak 34 jiwa. Data yang didapatkan dari Dinas Kesehatan Kabupaten Banyumas 2012, AKI sebesar 129 per 100.000 kelahiran hidup dan AKB sebesar 8,11 per 1000 kelahiran penduduk. Data rujukan maternal risiko tinggi mencapai $20,05 \%$, sedangkan jumlah rujukan neonatal risiko tinggi mencapai $5,77 \%$. Cakupan K1 sebesar 99,25\%, cakupan kepemilikan buku KIA mencapai $98,77 \%$, angka ini masih dibawah target standar pelayanan minimal yang seharusnya mencapai $100 \% .^{3}$

Wilayah kerja Puskesmas Ajibarang I terdiri atas 8 desa dan dalam rentang waktu tahun 2011 - 2012, di daerah tersebut masih ditemukan kasus kematian ibu. Data rujukan tahun 2012, jumlah rujukan maternal risiko tinggi mencapai $37,52 \%$, sedangkan rujukan neonatal mencapai 7,37\%. Hasil penghitungan cakupan buku KIA di Kabupaten Banyumas, didapatkan cakupan buku KIA hanya sekitar 72,34\% sedangkan cakupan kunjungan pertama ibu hamil (K1) sekitar 72,34\%. Cakupan buku KIA dan cakupan K1 masih dibawah target standar pelayanan minimal yang 100\%.3,4 Fungsi buku KIA sebagai sarana pencatatan status kesehatan ibu dan anak, sarana edukasi dan sarana informasi. ${ }^{5-6}$ Tujuan penelitian ini mengetahui hubungan fungsi pemanfaatan buku KIA meliputi fungsi pencatatan, edukasi, dan komunikasi dengan pengetahuan KIA pada ibu yang berada di wilayah kerja Puskesmas Ajibarang I.

\section{Metode}

Penelitian ini mengunakan desain studi potong lintang untuk menganalisis variabel sebab dan akibat yang terjadi pada objek penelitian yang dikumpulkan dalam waktu bersamaan. Populasi adalah ibu yang mempunyai anak berusia kurang dari 5 tahun yang berada di wilayah kerja Puskesmas Ajibarang I Kabupaten Banyumas, pada tahun 2012, berjumlah 966 orang. Besar sampel dihitung menggunakan rumus sampel minimal, jumlah sampel yang diambil sebanyak 91 responden yang diambil dari 8 desa di wilayah Puskesmas Ajibarang I, Kabupaten Banyumas meliputi Desa Ajibarang Kulon 15 responden, Ajibarang Wetan 8 responden, Pandansari 6 responden, Karangbawang 7 responden, Tipar Kidul 14 responden, Darmakradenan 12 responden, Kracak 15 responden, Ciberung 14 responden. Pengambilan sampel dilakukan dengan teknik proportional random sampling. Kriteria inklusi adalah ibu yang berdomisili di wilayah kerja Puskesmas Ajibarang I dan mempunyai buku KIA. Ibu dengan jumlah balita lebih dari satu. Observasi fungsi pencatatan buku KIA dilakukan pada buku yang dimiliki balita usia tertua. Kriteria eksklusi adalah ibu yang tidak bersedia menjadi responden.

Data diperoleh melalui wawancara menggunakan kuesioner tentang persepsi ibu terhadap peran tenaga kesehatan dalam pemanfaatan buku KIA. Penilaian fungsi pencatatan buku KIA dilakukan melalui observasi buku KIA yang dimiliki oleh ibu. Observasi kelengkapan buku KIA meliputi identitas ibu dan anak, catatan kesehatan ibu hamil, bersalin dan nifas, pelayanan $\mathrm{KB}$, kunjungan neonatal, catatan imunisasi dan pemberian vitamin, catatan Kartu Menuju Sehat (KMS), catatan perkembangan pada anak. Data pengetahuan KIA ibu diperoleh melalui wawancara menggunakan kuesioner terstruktur. Data dianalisis menggunakan analisis univariat meliputi persepsi ibu. Fungsi buku KIA meliputi pencatatan KIA, edukasi, dan komunikasi serta pengetahuan ibu tentang KIA. Kategori fungsi pencatatan lengkap jika hasil penilaian kelengkapan isian buku KIA mempunyai skor $\geq 8$, tidak lengkap jika skor $<8$. Kategori fungsi edukasi baik jika mempunyai skor $\geq 25$, kurang baik jika mempunyai skor $<25$. Kategori pengetahuan baik jika mempunyai skor $\geq 7$, kurang baik, jika skor $<7$. Kategori fungsi komunikasi baik jika hasil jawaban kuesioner tentang persepsi ibu dengan skor $\geq 32$, fungsi edukasi kurang baik jika skor $<32$. Analisis bivariat menggunakan uji statistik dengan uji kai kuadrat.

\section{Hasil}

Sebagian besar responden $(67,1 \%)$ berpendidikan dasar SD/SMP, sekitar 55\% berusia 25 - 29 tahun. Sekitar 52,74\% dengan tingkat pendapatan dibawah UMK Kabupaten Banyumas, tahun 2012 yang besarnya Rp750.000,00. Sebagian besar responden (56\%) mempunyai fungsi pencatatan buku KIA yang tidak lengkap, sekitar 57,1\% mempunyai fungsi edukasi buku KIA yang baik, sekitar $61,5 \%$ mempunyai fungsi komunikasi buku KIA yang baik (Tabel 1).

Ada hubungan fungsi pencatatan buku KIA dengan

Tabel 1. Karakteristik Responden

\begin{tabular}{llll}
\hline Variabel & Kategori & $\mathbf{n}$ & $\%$ \\
\hline Pendidikan & SMA/SMK & 30 & 32,9 \\
Usia (tahun) & SD/SMP & 61 & 67,1 \\
& $20-24$ & 10 & 11,0 \\
& $25-29$ & 50 & 55,0 \\
& $30-34$ & 12 & 13,2 \\
Pendapatan & $35-39$ & 8 & 8,8 \\
& $40-44$ & 11 & 12,0 \\
Persepsi fungsi pencatatan & Rendah & 48 & 52,7 \\
& Tinggi & 43 & 47,2 \\
Persepsi fungsi edukasi & Lengkap & 40 & 44,0 \\
& Tidak lengkap & 51 & 56,0 \\
Persepsi fungsi komunikasi & Kurang baik & 39 & 42,9 \\
& Baik & 52 & 57,1 \\
Pengetahuan & Kurang baik & 35 & 38,5 \\
& Baik & 56 & 61,5 \\
& Kurang baik & 40 & 44,0 \\
& Baik & 51 & 56,0 \\
\hline
\end{tabular}


Tabel 2. Hubungan Variabel Fungsi dengan Pengetahuan KIA

\begin{tabular}{lllllll}
\hline \multirow{2}{*}{ Variabel Fungsi } & & \multicolumn{3}{c}{ Pengetahuan KIA } \\
\cline { 3 - 5 } & Kategori & \multicolumn{2}{c}{ Kurang } & \multicolumn{2}{c}{ Baik } & \multirow{2}{*}{ Nilai p } \\
\cline { 3 - 5 } & & n & $\%$ & n & $\%$ & \\
\hline \multirow{2}{*}{ Pencatatan buku KIA } & Tidak lengkap & 12 & 30,0 & 28 & 70,0 & 0,031 \\
Edukasi buku KIA & Lengkap & 28 & 54,9 & 23 & 45,1 & \\
& Kurang & 13 & 33,3 & 26 & 66,7 & 0,120 \\
Komunikasi buku KIA & Baik & 27 & 51,9 & 25 & 48,1 & \\
& Kurang & 15 & 42,9 & 20 & 57,1 & 1,000 \\
& Baik & 25 & 44,6 & 31 & 55,4 & \\
\hline
\end{tabular}

pengetahuan ibu tentang KIA, tetapi fungsi edukasi dan fungsi komunikasi buku KIA tidak berhubungan dengan pengetahuan KIA. Ibu yang mempunyai pengetahuan KIA baik, mempunyai fungsi pencatatan buku KIA tidak lengkap sekitar $70 \%$, dibandingkan dengan ibu yang mempunyai fungsi pencatatan buku KIA lengkap sekitar $45,1 \%$ perbedaan tersebut secara statistik bermakna dengan nilai $\mathrm{p}=0,031$ (nilai $\mathrm{p} \leq 0,05$ ), berarti ada hubungan antara fungsi pencatatan buku KIA dengan pengetahuan KIA (Tabel 2).

\section{Pembahasan}

Pada penelitian ini, didapatkan hubungan antara fungsi pencatatan dengan pengetahuan KIA. Temuan ini berbeda dengan penelitian sebelumnya yang mengemukakan hubungan antara kelengkapan pengisian kolom buku KIA dengan pengetahuan ibu di Salatiga. Ibu-ibu yang mempunyai pengetahuan rendah cenderung tidak mengisi kolom pemantauan pertumbuhan anak, sedangkan ibu-ibu yang mempunyai pengetahuan baik akan mengisi buku KIA dengan lengkap. ${ }^{7}$ Pengisian buku KIA seyogyanya memberikan pemahaman pada ibu tentang status kesehatan diri dan anaknya. Penggunaan buku pegangan antenatal care oleh ibu merupakan salah satu intervensi dalam upaya peningkatan informasi. Catatan yang lengkap akan mendukung peningkatan pengetahuan ibu tentang kesehatan diri dan kesehatan anak-anak. ${ }^{8}$

Penelitian ini menemukan hubungan fungsi pencatatan buku KIA dengan pengetahuan KIA, tetapi dengan hasil terbalik, ibu yang mempunyai catatan buku KIA tidak lengkap justru mempunyai tingkat pengetahuan yang baik, dibandingkan dengan ibu yang mempunyai catatan lengkap. Catatan buku KIA lengkap lebih banyak didapatkan pada ibu dengan tingkat ekonomi rendah, serta cenderung secara rutin memanfaatkan layanan posyandu dibandingkan dengan ibu dengan tingkat ekonomi tinggi yang cenderung jarang memanfaatkan layanan posyandu. Ibu yang mempunyai tingkat ekonomi tinggi cenderung merupakan ibu bekerja yang juga tergolong mempunyai tingkat pendidikan menengah.

Tingkat pengetahuan dilandasi oleh tingkat pendi- dikan formal, sebagian besar $(67,04 \%)$ responden sudah mempunyai kategori tingkat pendidikan dasar. Pada level pendidikan ini, ibu sudah banyak mengerti pengetahuan tentang KIA secara umum yang tidak hanya didapat melalui buku KIA, tetapi juga melalui interaksi ibu dengan tenaga kesehatan. Media KIA kesehatan yang beraneka ragam juga semakin banyak menjangkau masyarakat sehingga tingkat pengetahuan yang didapatkan melalui interaksi tersebut semakin meningkatkan pemahaman ibu tentang informasi kesehatan ibu dan anak.

Semakin bertambah umur seseorang, semakin berkembang pula daya tangkap dan pola pikir sehingga pengetahuan yang diperoleh semakin membaik. Responden dalam penelitian ini sebagian besar $(55 \%)$ berada dalam rentang usia 25 - 29 tahun. Hal tersebut menjadi dasar banyak responden yang tergolong usia produktif yang berdampak pada ingatan informasi yang diperoleh sehingga pengetahuan juga sudah baik.

Buku KIA adalah buku catatan terpadu yang digunakan dalam keluarga dengan tujuan meningkatkan praktik keluarga dan masyarakat dalam pemeliharaan atau perawatan kesehatan ibu dan anak serta meningkatkan kualitas pelayanan KIA. Pencatatan buku KIA dilakukan oleh bidan desa serta dan dapat dibantu oleh kader dalam penyelenggaraan posyandu. ${ }^{9}$ Pencatatan buku KIA yang lengkap tetap harus diperhatikan oleh ibu, meskipun hasil penelitian pencatatan buku KIA yang lengkap lebih banyak dilakukan oleh ibu yang mempunyai pengetahuan kurang baik dibandingkan pencatatan yang tidak lengkap. Pencatatan berhubungan dengan riwayat kehamilan dan persalinan ibu. Selain itu, untuk anak berhubungan dengan status pertumbuhan dan perkembangan, status imunisasi yang berguna sebagai informasi bagi tenaga kesehatan lain serta sebagai informasi status kesehatan ibu dan anak bagi keluarga.

Penelitian ini menemukan ibu yang mempunyai fungsi pencatatan buku KIA yang tidak lengkap lebih banyak yang mempunyai pengetahuan yang baik. Hal tersebut dapat disebabkan pengisian buku KIA oleh tenaga kesehatan hanya kolom isian Kartu Menuju Sehat (KMS). Ibu juga hanya mempergunakan buku KIA untuk dibawa saat 
penimbangan balita di posyandu dan pada saat pemanfataan layanan kesehatan ke bidan desa dan puskesmas. Pencatatan status kesehatan ibu dan anak di buku KIA mempunyai keuntungan bagi ibu dan keluarga, kader kesehatan, serta tenaga kesehatan. Catatan status kesehatan di buku KIA berlanjut dari pencatatan ibu hamil, persalinan dan catatan tumbuh kembang anak. Catatan kesehatan tersebut dapat digunakan sebagai catatan penghubung riwayat penggunaan pelayanan kesehatan terendah sampai dengan sarana rujukan yang mungkin diakses pada saat mengakses layanan kesehatan tingkat lanjut. Pencatatan di buku KIA juga mempunyai kelemahan antara lain catatan kesehatan tersebut dapat hilang jika buku KIA yang digunakan tidak disimpan dengan baik.

Di Norwegia, tidak ada efek terhadap pengetahuan para orang tua terutama ibu melalui catatan tentang pemanfaatan pelayanan kesehatan. Catatan status kesehatan ibu dan anak merupakan sarana yang tepat untuk meningkatkan interaksi antara ibu dan tenaga kesehatan, sehingga ibu dapat menyimpan catatan kesehatan untuk tahun berikutnya atau sebelumnya. Ibu yang mempunyai catatan status kesehatan yang lengkap merasa lebih percaya diri, ibu juga dapat membagi informasi catatan tentang status kesehatan kepada keluarga sehingga dapat menjadi sumber informasi bagi mereka. Ibu minimal merasakan kekhawatiran jika kehilangan catatan status kesehatan. Orang tua yang menyimpan catatan kesehatan anak mempunyai persepsi positif akan penyelenggaraan layanan kesehatan. ${ }^{10-12}$

Dilihat dari karakteristik sosial ekonomi, wilayah Puskesmas 1 Ajibarang tergolong jauh dari pusat kota. Sebagian besar aktivitas kegiatan sosial ekonomi di masyarakat masih terpusat pada perdagangan dan pertanian. Dilihat dari karakteristik pedesaan yang masih melekat, di wilayah Puskesmas 1 Ajibarang, karakteristik pendapatan sebagian besar responden mempunyai tingkat pendapatan dibawah UMK Kabupaten Banyumas $(52,74 \%)$.

Perilaku pemanfaatan pelayanan kesehatan tradisional lebih banyak dilakukan oleh wanita yang berada di daerah perdesaan dengan tingkat sosial ekonomi yang rendah dibandingkan dengan wanita dengan tingkat sosial ekonomi yang tinggi. ${ }^{13}$ Di Bangladesh, ibu yang mempunyai buku KIA mempunyai pengetahuan KIA dan perilaku yang lebih baik tentang KIA karena mempergunakan buku KIA dengan baik pula, dibandingkan kelompok kontrol pada ibu yang tidak mempunyai buku KIA. ${ }^{12}$

Penelitian ini tidak menemukan hubungan antara fungsi edukasi dengan pengetahuan KIA. Sesuai dengan penelitian sebelumnya, yang tidak menemukan hubungan antara pengalaman ibu dalam memahami buku KIA (fungsi edukasi) dengan pengetahuan tentang KIA pada ibu-ibu hamil di Kecamatan Limbangan, Kabupaten
Kendal. ${ }^{14}$ Penggunaan buku KIA tidak serta merta meningkatkan pengetahuan ibu, bahwa sekitar 40\% ibu di Tanah Datar dan 57\% di Padang Pariaman belum pernah membaca atau telah membaca setiap bagian buku KIA atau hanya membaca sebagian kecil. Selain itu, di antara ibu yang telah membaca buku KIA setidaknya bagian dari buku KIA, meliputi di Tanah Datar sekitar $22,4 \%$ dan di Padang Pariaman sekitar 27\% menyatakan menemukan kesulitan memahami buku KIA tersebut. Ibu yang mempunyai buku KIA tidak berhubungan dengan pengetahuan yang lebih besar, tetapi mempunyai kecenderungan besar untuk mengetahui kepentingan antenatal care serta maksud pemberian imunisasi. ${ }^{16}$ Peningkatan cakupan pemberian imunisasi pada anak berhubungan dengan pelaksanaan program buku KIA. Buku KIA merupakan sarana yang dapat digunakan sebagai upaya peningkatan kesadaran ibu dan tenaga kesehatan akan pentingnya pemberian imunisasi bagi bayi dan anak.

Pada penelitian ini, berdasarkan persepsi ibu sekitar 69,2\% menyatakan kader menginformasikan pada para ibu untuk membaca buku KIA. Namun, informasi pada buku KIA tidak mengendap menjadi ingatan dan pengetahuan. Kemungkinan responden mempunyai kesan yang kurang mendalam terhadap informasi buku KIA sehingga tidak merasa termotivasi untuk menjadikan bagian kebutuhan. Selain itu, kegiatan belajar kelompok untuk memahami informasi buku KIA masih jarang dilakukan oleh kader atau petugas kesehatan. Di Cakranegara, tingkat pendidikan yang baik berhubungan dengan status kesehatan yang baik pula. Ada hubungan yang bermakna antara tingkat pendidikan dan efektivitas buku KIA dengan tingkat pengetahuan ibu tentang KIA. ${ }^{17}$

Tingkat pendidikan ibu seluruhnya termasuk dalam kategori pendidikan menengah dan pendidikan formal yang telah ditempuh adalah pendidikan dasar sehingga tingkat pengetahuan ibu tentang KIA dirasa sudah baik sehingga sebagian besar (56\%) responden mempunyai tingkat pengetahuan yang baik pula. Penggunaan buku pegangan antenatal care oleh ibu merupakan salah satu intervensi dalam upaya peningkatan informasi, pengetahuan dan komunikasi pada ibu, antara lain menumbuhkan kewaspadaan tentang masalah kesehatan reproduksi. Pengembangan buku pegangan antenatal care bertujuan memberikan informasi kepada ibu hamil serta sebagai pedoman dalam merawat dan mengasuh anak. ${ }^{8}$

Di Palestina, ibu yang mempunyai buku KIA lebih sering berkunjung ke pelayanan kesehatan dibandingkan ibu yang tidak mempunyai buku KIA. Ibu yang memilki buku KIA walaupun berpengetahuan kurang karena jarang/tidak membaca informasi di buku KIA, terbiasa dengan informasi kesehatan karena tenaga kesehatan mempergunakan buku KIA sebagai panduan dalam pemberian informasi/layanan KIA. ${ }^{18}$ Buku KIA merupakan buku wajib untuk dibaca oleh ibu hamil dan keluarga 
karena berisikan informasi penting dan berguna bagi kesehatan ibu dan anak. Penggunaan buku KIA secara baik tidak terlepas dari penyuluhan oleh bidan dan tenaga kesehatan lain pada setiap kunjungan ibu hamil. ${ }^{19}$

Pemanfaatan buku kesehatan ibu dan anak dapat diamati dari kepemilikan buku KIA. Ibu membawa buku KIA ketika berkunjung ke fasilitas pelayanan kesehatan/menghadiri kegiatan berhubungan program KIA telah menerima informasi dari penyedia layanan kesehatan yang menggunkan buku KIA tersebut. Selanjutnya, ibu telah membaca pesan/informasi yang ada dalam buku KIA tersebut. Selain itu, kemudahan ibu dalam memahami informasi kesehatan/pendidikan kesehatan menjadi determinan penting pengetahuan ibu. ${ }^{20}$

Penelitian ini tidak menemukan hubungan fungsi komunikasi dengan pengetahuan KIA, berbeda dengan penelitian sebelumnya yang menemukan hubungan yang secara statistik bermakna antara pemanfaatan buku KIA sebagai media penyuluhan dengan pelayanan antenatal care. Semakin ibu memanfaatkan media penyuluhan (fungsi komunikasi) dalam buku KIA semakin meningkat pengetahuan sehingga banyak memanfaatkan pelayanan antenatal care yang dilakukan oleh petugas kesehatan, demikian pula sebaliknya. ${ }^{20}$ Temuan penelitian ini juga sesuai dengan penelitian lain yang tidak menemukan hubungan antara kepemilikan buku KIA dengan pengetahuan praktik perawatan kehamilan. Tidak ada hubungan antara kepemilikan buku KIA, sikap dan praktik perawatan kehamilan dengan pengetahuan ibu. ${ }^{21}$

Buku KIA yang dapat berfungsi sebagai alat komunikasi antara tenaga kesehatan dengan pasien, diharapkan meningkatkan partisipasi masyarakat dalam mengontrol kesehatan ibu. Penggunaan buku KIA merupakan salah satu strategi pemberdayaan masyarakat terutama keluarga untuk memelihara kesehatan dan mendapatkan pelayanan kesehatan yang berkualitas. ${ }^{20}$ Buku KIA disebut sebagai alat komunikasi karena tenaga kesehatan dapat mengingatkan catatan-catatan penting yang dapat dibaca oleh tenaga kesehatan lain dan ibu serta keluarga. Hal tersebut antara lain keluhan, hasil pemeriksaan, catatan persalinan, pelayanan yang diberikan kepada ibu/bayi/anak balita, hasil pemeriksaan tambahan dan rujukan. Manfaat buku KIA bagi tenaga kesehatan adalah alat pencatatan, pemantauan dan rujukan kesehatan ibu dan anak, alat komunikasi dan penyuluhan KIA, alat untuk mendeteksi secara dini gangguan/masalah KIA.

Pemanfaatan buku KIA oleh tenaga kesehatan masih tidak banyak dilakukan. Hasil penelitian pada bidan desa di Kabupaten Banyumas menyebutkan bahwa ada hubungan antara supervisi dengan peran pengisian buku KIA. Dari hasil penelitian tersebut, tenaga kesehatan masih belum maksimal mempergunakan buku KIA sebagai media komunikasi, informasi dan edukasi kesehatan ibu dan anak sehingga perlu upaya kader dalam penggunaan buku KIA. 22,23 Komunikasi, informasi, dan edukasi kesehatan melalui pemanfaatan buku KIA dapat dilakukan sebagai komunikasi tenaga kesehatan kepada ibu, walaupun ibu mampu membaca sendiri pesan/informasi KIA yang dalam buku KIA, tidak setiap ibu mempunyai waktu/kesempatan untuk membaca pesan/ informasi tersebut. Catatan tentang masalah penyakit, tumbuh kembang anak belum sepenuhnya dipahami dan dapat diintepretasikan dengan baik oleh ibu sehingga perlu upaya komunikasi dari tenaga kesehatan untuk dapat menjelaskannya dengan baik.

Pemanfaatan buku KIA oleh tenaga kesehatan perlu dimodifikasi, khususnya dalam menggabungkan informasi/pesan supaya lebih menarik, mudah dipahami sebagai cara untuk menyampaikan pesan tersebut. Tenaga kesehatan juga perlu mempertimbangkan tingkat pendidikan kelompok sasaran. Hal tersebut merupakan upaya peningkatan efektivitas kegiatan berbasis masyarakat dalam mempromosikan pengetahuan dan perilaku ibu dalam kesehatan ibu dan anak. Pemanfaatan buku KIA dalam sesi pendidikan kesehatan akan mendorong komunikasi yang efektif antara ibu dengan tenaga kesehatan. Dukungan tenaga kesehatan dapat diberikan ketika ibu memanfaatkan fasilitas pelayanan kesehatan, tenaga kesehatan dapat menjelaskan poin penting karena ibu belum memahami informasi kesehatan ibu dan anak. ${ }^{15}$

\section{Kesimpulan}

Ada hubungan yang bermakna antara fungsi pencatatan dengan pengetahuan KIA, tetapi tidak ada hubungan antara fungsi edukasi dan fungsi komunikasi dengan pengetahuan KIA.

\section{Saran}

Pencatatan buku KIA berhubungan dengan status kesehatan ibu dan anak sehingga memerlukan peran serta ibu untuk menilai kelengkapan isian catatan buku KIA. Perlu peningkatan pencatatan kelengkapan isian buku KIA oleh tenaga kesehatan karena hasil pencatatan dapat berkaitan dengan pengetahuan KIA.

\section{Daftar Pustaka}

1. Kementerian Kesehatan Republik Indonesia. Survei demografi dan kesehatan Indonesia tahun 2012. Jakarta: Kementerian Kesehatan Republik Indonesia; 2012.

2. Dinas Kesehatan Provinsi Jawa Tengah. Profil kesehatan Provinsi Jawa Tengah tahun 2012. Semarang: Dinas Kesehatan Jawa Tengah; 2012.

3. Dinas Kesehatan Kabupaten Banyumas. Profil kesehatan Kabupaten Banyumas tahun 2012. Banyumas: Dinas Kesehatan Kabupaten Banyumas; 2012.

4. Siti N, Colti S, Eri W. Pemantauan pencapaian cakupan K1, cakupan K4, cakupan buku KIA dan kualitas pelayanan antenatal di wilayah ker- 
ja puskesmas di Kabupaten Banyumas. Prosiding Seminar Nasional World fit for children [6 Oktober 2012]. 2012. Semarang: Fakultas Kesehatan Masyarakat Universitas Diponegoro; 2012.

5. Departemen Kesehatan Republik Indonesia. Pedoman umum manajemen penerapan buku KIA. Jakarta: Departemen Kesehatan Republik Indonesia; 2003.

6 Syafiq A, Fikawati S. Kepemilikan buku kesehatan ibu dan anak (KIA) dan pelayanan KIA. Depok: Fakultas Kesehatan Masyarakat Universitas Indonesia; 2007.

7. Djaswadi D. Persepsi perilaku ibu hamil dan masyarakat terhadap risiko kehamilan-persalinan di Kabupaten Purworejo. Yogyakarta: Laboratorium Penelitian Kesehatan dan Gizi Masyarakat; 2008.

8. Akhund S, Avan BI. Development and pretesting of an information, education and communication (IEC) focused antenatal care handbook in Pakistan. Journal of Biomedical Central. 2011; 4: 91.

9. Departemen Kesehatan Republik Indonesia. Petunjuk teknis penggunaan buku KIA. Jakarta: Departemen Kesehatan Republik Indonesia; 2003.

10. Chakraborty N, Islam MA, Chowdhury RI, Bari W, Akhter HH. Determinants of the use maternal health services in rural Bangladesh. Health Promotion International Journal, 2003 ; 18 (4): 327-37.

11. Turner KE, Fuller S. Patient-held maternal and/or child health records: meeting the information needs of patients and healthcare providers in developing countries? Journal of Public Health Informatics [serial on internet]. 2011 [cited 2014 Jan 5]; 3 (2); 48. Available from: http://ojphi.org.

12. Bhulyan SU, Nakamura Y, Qureshi NA. Study on the development and assesment of maternal and child health (MCH) handbook in Bangladesh. Journal of Public Health and Development. 2006; 4 (2): 45-60.

13. Amin R, Shah NM, Becker S. Sosioeconomic factors differentiating maternal and child health-seeking behavior in rural rural Bangladesh; a cross sectional analysis. International Journal of Equity in Health [serial on internet]. 2010 [cited 2013 Dec 5]. Available from: http://www.equityhealthj.com/content/9/1/9.

14. Dora D. Faktor-faktor yang berhubungan dengan tingkat pemahaman ibu hamil terhadap pesan antenatal care yang terdapat di dalam buku KIA [tesis]. Semarang: Fakultas Kedokteran; 2010.
15. Kusumayati A, Nakamura Y. Increased utilization of maternal health services by mothers using maternal and child health book in Indonesia. J It Health [serial on internet]. 2007 [cited 2014 Jan 5]; 22 (3): 143-51. Available from: https:// www. jstage. jst. go.jp /article /jaih /22/ 3/ 22 3_ 143/_pdf.

16. Osaki K, Hattori T, Kosen S, Singgih B. Investment in home-based maternal, newborn and child health records improves immunization coverage in Indonesia. Transaction of The Royal Society of Tropical Medicine and Hygiene [serial on Internet]. 2009 [cited 2014 Jan 4]; 103 (8): 846-8. Available from: http://PubMed PMID.

17. Rante A, Susilo W, Faikah. Studi deskriptif dan analisis faktor yang berpengaruh dalam tingkat pengetahuan KIA pada ibu di Puskesmas Cakaranegara Mataram. Jurnal Kesehatan Prima. 2007; 1: 9384.

18. Hagiwara A, Veyama M, Ramiawi A, Sawada I. Is the maternal and child health $(\mathrm{MCH})$ handbook effective in improving health-related behavior? evidence from Palestine. Journal of Public Health Policy [serial on the internet]. 2013 [cited 2013 Jul 5]; 34 (1): 31-45. Available from: http://www.ncbi.nlm.nih.gov/pubmed/23151920.

19. Widaningrum D, Wirawan W, Hasanbasri M. Implementasi buku kesehatan ibu dan anak di Kabupaten Mimika [tesis]. Yogyakarta: Universitas Gadjah Mada; 2009.

20. Nur E, Werdiati K. Pemanfatan buku KIA sebagai materi penyuluhan dalam pelayanan antenatal oleh bidan puskesmas di Kota Bengkulu. Jurnal Manajemen Pelayanan Kesehatan. 2003; 6 (3).

21. Kusindijah. Hubungan antara kepemilikan buku KIA dengan pengetahuan, sikap, dan praktik perawatan kehamilan di wilayah kerja Puskesmas Rangkah Surabaya. Embrio Jurnal Kebidanan. 2012; 1 (1): 42-6.

22. Colti S, Siti N, Suratman. Faktor-faktor yang berhubungan dengan peran kader dalam pemanfataatan buku KIA di wilayah kerja Puskesmas Kalibagor Kabupaten Banyumas. Kemas Jurnal Kesehatan Masyarakat. 2013; 8 (2): 77-84.

23. Siti N, Colti S. Faktor-faktor yang berhubungan dengan peran bidan desa dalam pengisian buku KIA. Prosiding Seminar nasional: Pengembangan Sumber Daya Pedesaan dan Kearifan Lokal Berkelanjutan Lembaga Pengabdian Kepada Masyarakat Universitas. Purwokerto: Universitas Jenderal Soedirman; 2011. 